\title{
Childlessness of men in Canada: Result of a waiting game in a changing family context
}

\author{
Zenaida R. Ravanera* \\ Roderic Beaujot
}

\begin{abstract}
Childlessness was about 12-13 per cent for cohorts born in 1927 to 1941, but increased in younger cohorts, with the childlessness of men born in 1957-1961 reaching 20 per cent. Using data from the 2006 Canadian General Social Survey on families, we show that the intention to be childfree among young men has largely remained low, at 8 to 10 per cent. As men grow older, the intention to be childfree increases such that at age 45-49, 16 per cent intend not to become fathers. Rather than a deliberate choice, the increase in childlessness could be the result of a waiting game. Longer stays in school, later entry into the work force, and starting marital relations at older ages contribute to delays in becoming fathers. While for many men the delay does not necessarily end in childlessness, for others the period of waiting changes their intention to become fathers. The adjustment of intentions and the eventual childlessness are made easier because of the reduced normative pressure to have children.
\end{abstract}

Keywords: men's fertility, childlessness, fertility intention, fatherhood.

\section{Résumé}

L'infécondité représentait de $12 \%$ à $13 \%$ chez les cohortes nées entre 1927 et 1941; elle a fait un bond en avant chez les cohortes plus jeunes, le taux d'infécondité chez les hommes nés entre 1957 et 1961 atteignant 20\%. À partir des données de l'Enquête sociale générale sur la famille de 2006, nous démontrons que le désir, chez les hommes, de ne pas avoir d'enfant demeure essentiellement bas, soit de $8 \%$ à $10 \%$. Alors que les hommes avancent en âge, leur désir de ne pas avoir d'enfant s'accentue, au point où vers l'âge de 45 à 49 ans, $16 \%$ d'entre eux n'ont pas l'intention de devenir père. Au lieu d'être un choix délibéré, cette hausse d'infécondité pourrait résulter de la décision de reporter la paternité. Des études plus longues, une entrée tardive sur le marché du travail et le fait de s'installer en couple plus tard sont tous des facteurs qui contribuent au retard de la paternité. Bien que pour beaucoup d'hommes, ce retard n'entraîne pas nécessairement une infécondité, pour d'autres la période d'attente change leur intention de devenir père. Il est devenu plus facile d'accepter le changement du désir de paternité et l'infécondité éventuelle en raison de la pression normative réduite d'avoir des enfants.

Mots-clés : fertilité masculine, infécondité, intention de fertilité, paternité.

\section{Changing families and childlessness in Canada}

The level of childlessness has increased over cohorts of men and women born in the late 1920s and early 1930s (the parents of the baby boomers) to more recent cohorts born from the 1960s and later. This higher level of childlessness could be seen as part of the changes associated with the

* Zenaida R. Ravanera and Roderic Beaujot, Centre for Population, Aging, and Health, University of Western Ontario. Email: ravanera@uwo.ca. 
second demographic transition that has occurred in many Western countries starting in the 1960s (Lesthaeghe 1995).

The first demographic transition in Canada saw mainly a decrease in fertility (Beaujot and Muhammad 2006). The second demographic transition, which started in the late 1960s, brought about drastic changes in various facets of family life, including further declines in fertility, greater instability in marital relationships, and older ages at family transitions (Beaujot 2000). In 1951, for example, the average birth statistic per female was 3.5; by 1996 it had gone down to 1.6. Entries into marital relationships have changed, with cohabitation increasing in popularity at the expense of marriage. Common-law couples as a percentage of all couples were negligible until the 1970s; by 1996, 14 per cent of couples were in cohabiting unions. There were 180 divorces for every 100,000 marriages in 1951; this increased to 1,222 by 1996 (Beaujot 2000: 89). As for age at transition to family life, men born in 1926-1930 got married at 26 and became parents at 28 years old, whereas men born in 1966-1970 married at 31 and became parents at 32 years of age (Ravanera et al. 2006).

Childlessness is not often explicitly included in the discussion of these changes to family life associated with the second demographic transition. However, it is easy to deduce that childlessness could stem from these family changes: fertility below replacement level implies that a greater proportion of men and women have had only one or no child at all; when marital relations are less stable, more men and women would not enter into long-term commitments that include parenthood; and biological imperatives and life course pathways indicate that delays in having children would lead to inability or unwillingness to have children at older ages.

With the second demographic transition in the 1960s, the period of the "child-king," where children were the focus of family life, essentially ended (Aries 1980), replaced by preference for "pure relationship" in couples for whom children are not essential for self-fulfillment and satisfactory quality of dyadic relationships (Beaujot 2000: 118). Despite these changes in family life, however, children remain an important part of people's lives. Using data from the General Social Surveys, we show below that most people intend to have children at some time in their lives, but the intention becomes unrealized for an increasing number of Canadians as their life course unfolds.

Life course transitions that constitute people's conjugal and family trajectories, including the transition to parenthood, are dependent on events experienced earlier in life. Since choices are constrained by the life course trajectory that one has taken, developmental psychologists use the concept of "constrained pathway" (Heckhausen 1999). That is, once a pathway is taken, some transitions become more difficult. For instance, those who pursue higher education have a higher probability of entering the labour force rather than entering marriage as their next transition. This especially holds for men, but increasingly for women as well (Goldscheider et al. 2006). Having postponed marriage in favour of education and work, they would be less likely to make the transition to parenthood than those who have entered into marriage first before pursuing higher education or work (Ravanera et al. 2006).

Life course constraints are particularly relevant in understanding childlessness. While becoming a parent is a priority for young people, this comes third in the sequence of events-behind the achievement of two other goals in life: having satisfying work and living in an enduring union (LapierreAdamcyk 1990). Difficulties in establishing one's work life and in having an enduring relationship can interfere with the original desire to have children. In a study of childlessness using longitudinal data from a national survey in the United States, Heaton et al. (1999: 538) found that the largest group in their analysis are men and women of childbearing age who postpone parenthood. They noted that as these men and women grow older, their chances of having a child decrease because of "biological processes and lifestyle preferences that make childbearing less attractive." Veevers (1980: 20-29) 
argues that most couples do not make direct decision to be childless. Rather, childlessness is a result of a "waiting game," or a series of postponements of childbearing. That is, the transition from wanting to not wanting children occurs in stages, the first of which is postponing childbearing for a definite time (say, after getting a satisfactory job), followed by postponement for an indefinite time (until the couple feels ready to have a child); then there may be a period of deliberation of the pros and cons of parenthood, acknowledging the possibility of not having children; and finally, acceptance of permanent childlessness. For many, then, childlessness is a result of sequential decision-making under structural constraints, with the decisions reinforced by changing norms of childbearing. The following sections expand on these topics of structural and normative constraints.

\section{Structural constraints}

The changes brought about by the second demographic transition are often related to changes in the lives of women, particularly the significant increases in women's school attendance and participation in the labour force since the late 1960s (Clark 2000; Morissette 2002; Beaujot et al. 2007). However, with varied and rapid changes in families that have been taking place since the 1960 s, focusing on women alone is no longer sufficient.

The changes in men's work patterns have been mainly in the opposite direction to those for women, though not as dramatic. Between 1961 and 1996, for example, women's participation rates increased from 29 to 58 per cent whereas men's rates decreased from 81 to 72 per cent (Beaujot 2000: 136). Of particular relevance to understanding childlessness are the changes experienced by young men, such as entry into marriage (and subsequently to parenthood), that are especially dependent upon men's earnings and career mobility (Oppenheimer and Lewin 1999). These changes have been less positive than those of older men. Over the period 1981-2001, for example, the proportion of men aged 16-24 who were non-students and working full-time declined from 78 to 69 per cent, and for ages 25-29, the proportion working full-time declined from 88 to 84 per cent (Morissette 2002: 33). Morissette also calculated that the earnings of full-year, full-time employees for both age groups of men declined over the same period. In comparison to older men, younger men are more disadvantaged in terms of proportion working, hours worked per week, and wages per hour. In more recent years, that is, between 1997 and 2007, the increase in earnings of employees (both men and women) under the age of 35 was greater than those of employees aged 35-54 (Morissette 2008). However, the study also mentions that the wages of newly hired employees have fallen substantially, and that the proportion of new employees, both male and female, hired for temporary jobs increased from 11 per cent in 1989 to 21 per cent in 2004 (Morissette 2008; Morissette and Johnson 2005).

In the context of rational decision-making process, the economic constraints and diminished opportunities for young men have a large role to play in the transitions to family life, with their impact evident in the delay in entry into marriage and parenthood (Ravanera et al. 2006). In a study of men's transition to parenthood using the 2001 General Social Survey on the family, Bingoly-Liworo (2010) shows that men with full-time jobs and men who are self-employed, with job duration lasting from 1 to 4 years, are more likely to become fathers compared to men who have part-time jobs. Likewise, men who have married before having their first job and have held their jobs from 1 to 4 years are more likely than cohabiting men to become first-time fathers. These findings indicate that economic stability and stability of relationships are conditions for becoming a parent, and conversely, uncertainty and job precariousness delay the transition to parenthood. 


\section{Normative constraints}

Behavioural changes and norms surrounding family life have changed in tandem. Of particular relevance to men's childlessness are norms about having children, about men as breadwinners, and about men's involvement in household chores and caring for children.

There have been increases in men's participation in unpaid work, including household tasks and caring for children, as evidenced by data gathered through surveys on time use. Between 1992 and 2005, the proportion of Canadian couples in shared models of earning and caring (that is, wife and husband spending about the same amount time doing unpaid work) increased from 23 to 27 per cent, and the proportion where husbands do more unpaid work while doing the same amount of paid work (referred to as "men's double-burden") has increased from 6 to 11 per cent (Beaujot et al. 2008; Ravanera et al. 2009). Even with these changes, however, women continue to be the main provider of unpaid work, especially when there are small children (Beaujot 2000).

Men's roles vis-à-vis children and the family have been changing, but one that continues is their responsibility to bring home resources. While the proportion of dual-earner families has increased in the past decades, data on gender difference in work participation when there are children indicate that men are still considered the main breadwinners. In 2005, for example, the labour force participation rates of men aged 20-64 are highest (at 94-96 per cent) for those who are married and have children under 12 in the household; whereas for women, the lowest participation rates are for those with at least one child under five years of age (46 per cent for married women and 55 per cent for not married women; Beaujot et al. 2010). Likewise, based on reviews of a number of studies on work interruptions, Beaujot (2000: 162) concludes that family responsibility "enhances the continuity of men's work but reduces the continuity of women's work."

These two norms reinforce decisions to postpone childbearing until couples are ready to have children. For men in particular, this means postponement until they have attained stability in the economic sphere and the capacity to take on a larger share of parenting tasks. As meeting these expectations becomes ever more difficult for many couples, a decision to remain childless is bolstered by the changing norm on childbearing. After the Second World War, especially with the generation that gave birth to the baby boom, fatherhood was considered a marker of manhood and evidence of maturity (May 1995: 136). There was strong pressure to have children, and the alternative of "childless by choice" faced significant opposition in family and social circles (Veevers 1980; Park 2002; Blackstone and Stewart 2012). This has largely changed with the second demographic transition, which brought about the understanding that fertility should be desired, and that it is legitimate to be "childfree" in the pursuit of alternative life goals. As May (1995: 184) notes, the increase of voluntary childlessness in the United States is also consistent with and supported by political philosophies such as feminism and environmentalism.

In sum, one of the changes brought about by the second demographic transition is an increase in levels of childlessness that is mainly an outcome of a "waiting game." At the outset, most men and women do not directly decide on being childless. However, as they go through their work and family life course, they are confronted with structural constraints leading to delays in childbearing, which for an increasing proportion of men and women ends in eventual childlessness. The decision to postpone is bolstered by norms about men's greater involvement in rearing children as well as greater tolerance for childlessness.

In this paper, we first show the trends in childlessness over cohorts of men, indicating that increases in childlessness started around the 1960s with the onset of the second demographic transition. Using data from the 2006 General Social Survey, we then show some evidence of the "waiting game" and the constraints that confront men. We do this by first examining the number of children 
men intended to have and the actual number of children that they do have. Through a multivariate analysis, we then examine the determinants or factors that influence men's childlessness, highlighting the structural and normative constraints to parenthood. Finally, to further support findings from the multivariate analysis, we look at the explicit reasons given by men as to why they intend to remain childfree, and the factors that they take into account when considering having a child. We conclude with discussions of the implications of our findings.

\section{Data and methods}

The General Social Survey on Family Transitions, conducted in 2006 by Statistics Canada, has for its target population all persons aged 15 years and older in Canada, excluding residents of the Yukon, Northwest Territories, and Nunavut, and full-time residents of institutions (Statistics Canada 2008). It gathered information about the respondents, as well as some information about their households. The topics covered included parental history, home-leaving, marital and common-law unions, fertility and fertility intentions, social networks, main work activities, and education.

The survey had 23,608 respondents, but for this paper we included only 4,894 men aged 20-49 as of the survey date. There were 5,439 men aged 20-49 in the survey; however, we excluded the 545 men who did not respond to the question on intended fertility, since fertility intention is a main focus of our analysis. The percentage distributions of men by education, religiosity, and region of residence do not differ between those who did and did not respond to the question on intended fertility. But they do differ in terms of other characteristics: those who did not respond are more likely to be younger, single, childless, working part-time, and have lower incomes.

With data that are cross-sectional and with no direct information on attitudes and beliefs, we bring into the analysis a semblance of sequential decision-making and the associated psychological processes, through separate analyses for three 10-year birth cohorts. By analyzing both childlessness and the intention to remain childfree for men in each of these birth cohorts, we can also capture the varying influence of background factors at different stages of the life course.

We first examine the differences in levels of childlessness and intentions to have children or to remain childfree, through cross-tabulation by a number of independent variables: age group and marital status (as life course indicators), religion, religiosity, and visible minority status (as indirect indicators of cultural values and norms), respondent's education, personal income, and work status (as indicators of structural variables at the individual level), and region of residence (to capture cultural and structural variations over geographic areas). We use these same independent variables for the multivariate analysis, for which we did three logistic regression models. For the dependent variable in Model 1, the childless are assigned a value of " 1 " and those who have children are assigned a value of " 0 ." This focuses on actual behaviour — that is, the childless are contrasted with fathers. In Model 2, men intending to remain childfree are assigned a value of " 1 ," and those who have or are intending to have children are assigned a value of " 0 ". This models the intention - that is, men who intend to be childfree, in contrast to those who already have or intend to have children. Finally, in Model 3, the analysis is confined to the childless, with those intending to remain childfree assigned a value of " 1 " and those intending to have a child a value of " 0. " This models the intention of remaining childfree for men who are childless as of the survey date. Fractional sampling weights were used in all the analyses.

Results are presented mainly for 10-year birth cohorts and, when deemed appropriate, by 5-year birth cohorts. The results in their entirety can be found in Appendix Table 1 for the bivariate analysis and in Appendix Table 2 for the multivariate analysis. For ease in presentation, parts of the Appendix 
Tables are extracted and embedded in the discussion as Tables 2, 4, and 6 (for the bivariate analysis) and Tables 3, 5, and 7 (for the multivariate analysis).

Both bivariate and multivariate analyses examine the relationships between individual characteristics, on the one hand, and behaviour (here, childlessness) and intention (to remain childfree), on the other. To supplement the findings from these analyses, we also examined the responses to questions pertaining to reasons for not having a/another child, and to factors considered important in having a/another child.

\section{Trends in childlessness: Men and women compared}

In Canada, the estimate of the level of childlessness based on the 1991 Census shows that the lowest levels were for cohorts of women born from around 1927 to 1941, at about 12-13 per cent (Table 1). The rate increased to 14 per cent with the 1942-1946 birth cohorts and continued to increase with the succeeding cohorts. The childlessness of men could not be estimated using the 1991 Census $^{\dagger}$ (as the question on the number of children ever fathered was not asked of men), but it would be reasonable to surmise that the trend of childlessness over cohorts is similar to that of women.

\begin{tabular}{|c|c|c|}
\hline \multirow{2}{*}{$\begin{array}{l}\text { Birth } \\
\text { cohort* }\end{array}$} & \multicolumn{2}{|c|}{$\%$ childless } \\
\hline & Women & Men \\
\hline 1906-+ & 21.7 & \\
\hline $1907-1911$ & 22.0 & \\
\hline 1912-1916 & 19.9 & \\
\hline 1917-1921 & 16.9 & \\
\hline 1922-1926 & 15.0 & \\
\hline 1927-1931 & 13.1 & \\
\hline 1932-1936 & 12.5 & \\
\hline 1937-1941 & 12.2 & \\
\hline 1942-1946 & 13.9 & \\
\hline 1947-1951 & 14.4 & 17.3 \\
\hline 1952-1956 & 16.6 & 18.1 \\
\hline 1957-1961 & 17.4 & 19.5 \\
\hline 1962-1966 & 19.5 & 24.4 \\
\hline 1967-1971 & 20.4 & 30.3 \\
\hline $1972-1976$ & 30.5 & 48.3 \\
\hline
\end{tabular}

The data from the 2006 survey allow an estimation of childlessness for both men and women, which we have done from cohorts born from 1947-1951 (aged 51-55 years as of the survey date). As can be seen in Table 1, the level of childlessness is higher for men than for women for all birth cohorts. One apparent reason is that men become fathers at older ages than women, which would explain much of the differences among younger people, from the 1962-1966 to the 1972-1976 birth cohorts. These cohorts of men were aged 30-34 to 40-44 in 2006, the year when the survey was conducted. That is, many in these cohorts would become fathers and would complete their reproductive life after the survey and at older ages than women from the same cohorts. However, this explanation would not be adequate for the 2-3 per cent differences in childlessness for the older cohorts (aged

† The 1991 Canadian Census was the last census that asked women about the number of children ever born. 
45-59 as of 2006), as most of the men who became fathers would have already gone through their transition to fatherhood by the survey date.

One possible explanation that we have explored with the 2006 survey data is that there could be a smaller proportion of men becoming parents. This could happen if a significant number of nevermarried women subsequently have children with men who had children in previous unions, rather than with men who were previously never married and never had children. Data from the survey do not provide strong evidence of this explanation.

Another likely explanation for the gender difference in childlessness is one cited in the literature for the lower fertility of men than women, which is that men underreport fertility in surveys, particularly non-marital births and births in unions that have subsequently dissolved (Rendall et al. 1997). Juby and Le Bourdais (1999) found that this type of underreporting has occurred in the 1995 General Social Survey in Canada. We have not examined underreporting in the 2006 GSS, as this would necessitate a separate study. However, we do note that while the levels of childlessness differ, the trends over cohorts are similar for men and women.

\section{Results of analysis of childlessness}

We discuss the results by 5-year and 10-year age groups sequentially, as though we are tracing the experiences of a cohort of men. However, the data are cross-sectional, gathered at one point in time, and thus, the results apply to a "synthetic" rather than a real cohort of men.

\section{The waiting game: Intention and behaviour}

The intention to be childfree is low among young Canadian men. The data from the 2006 GSS show that at age 20-24, only 8 per cent intend to be childfree, which rises to 9.2 per cent at age 25-29

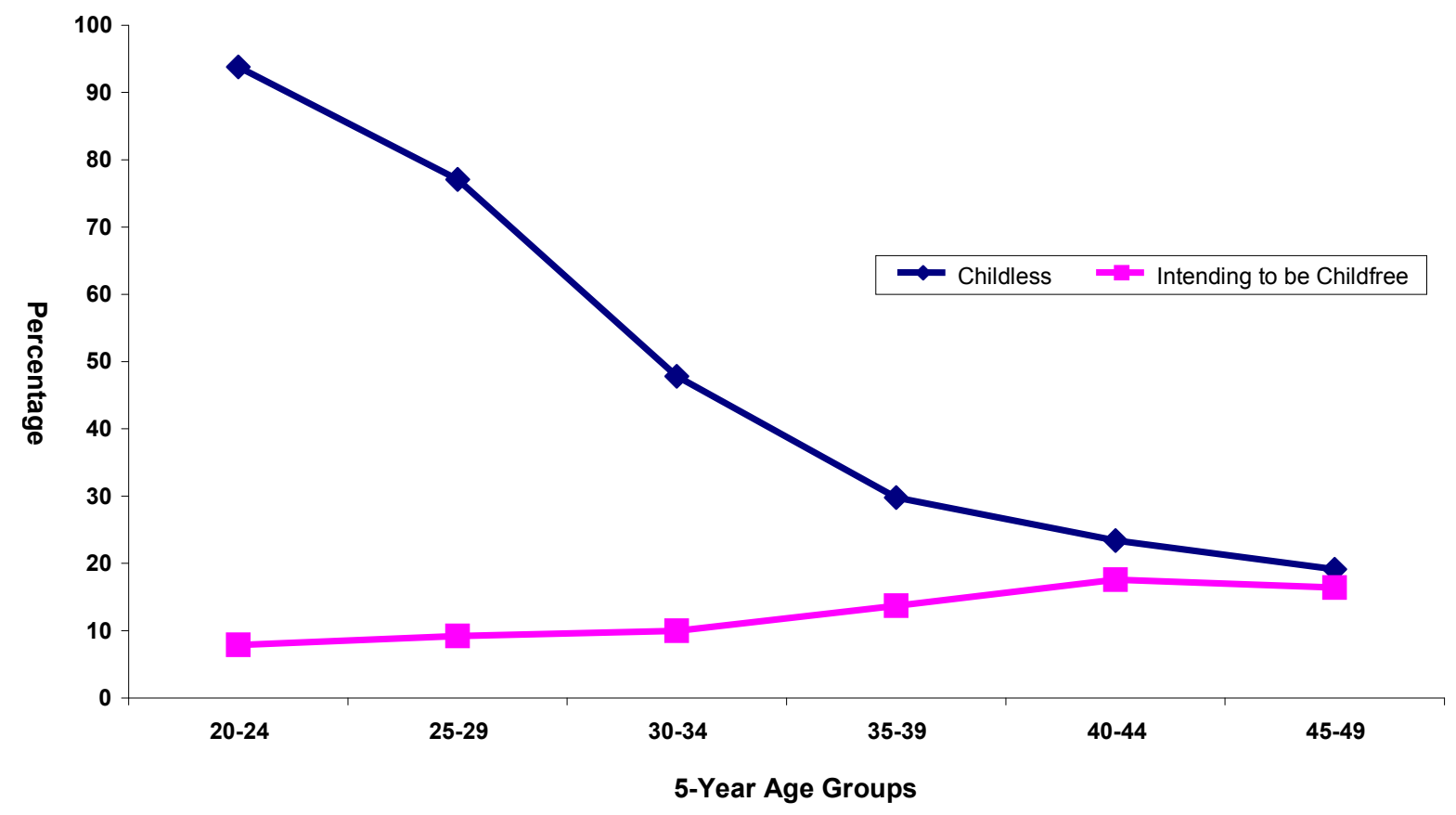

Figure 1. Proportion (percentage) childless and intending to be childfree men aged 20-49 by 5-year age groups, 2006. Source: 2006 General Social Survey. 
and 10 per cent at 30-34 years (Figure 1). These are similar to the estimates using the 2001 Canadian General Social Survey on Family History, showing that the proportion intending to remain childfree is at 6-9 per cent for men and women aged 20-34 (Stobert and Kemeny 2003). This low proportion intending not to have children provides support to the contention that most young Canadians anticipate having children in their eventual family life.

While the proportions intending to remain childfree are low at young ages, intention to become childfree increases as men get older, such that at age 35-39 the proportion intending to remain childfree reaches 14 per cent, an increase of 4 per cent over those of men aged 30-34. The proportion intending to remain childfree increases further to 18 per cent at age 40-44, and at age 45-49, acceptance of permanent childlessness becomes evident - with 16 per cent of men intending to be childfree.

Figure 1 also shows that the actual proportions childless are high — 94 per cent for age 20-24 - but decrease with age as men do become fathers as they grow older, with the proportion childless at 48 per cent by age 30-34 and 30 per cent by age 35-39. The narrowing gap between the intention to remain childfree and the proportion actually childless is brought about by two contrasting trends as men grow older: many make the transition to parenthood, but the proportion intending to be childfree also increases.

\section{Transition to family life and childlessness}

Childlessness is greatly dependent not only on age but also on the family life course stage; that is, those who have made the transitions to having a marital relationship are less likely to be childless or

Table 2. Proportion (\%) of childless men aged 20-49 by intention to have children by family life course indicators and by 10-year age groups, 2006.

\begin{tabular}{|c|c|c|c|c|c|c|c|c|c|c|c|c|}
\hline \multirow[b]{2}{*}{$\begin{array}{c}\text { Explanatory } \\
\text { Variables }\end{array}$} & \multicolumn{4}{|c|}{ Age Group 20-29 } & \multicolumn{4}{|c|}{ Age Group 30-39 } & \multicolumn{4}{|c|}{ Age Group 40-49 } \\
\hline & $\mathrm{N}$ & $\begin{array}{l}\text { Total } \\
\text { child- } \\
\text { less }\end{array}$ & $\begin{array}{l}\text { Intend } \\
\text { No } \\
\text { child }\end{array}$ & $\begin{array}{c}\text { to have } \\
\begin{array}{c}\text { Child- } \\
\text { ren }\end{array}\end{array}$ & $\mathrm{N}$ & $\begin{array}{c}\text { Total } \\
\text { child- } \\
\text { less }\end{array}$ & $\begin{array}{l}\text { Intend } \\
\text { No } \\
\text { child }\end{array}$ & $\begin{array}{c}\text { to have } \\
\text { Child- } \\
\text { ren }\end{array}$ & $\mathrm{N}$ & $\begin{array}{c}\text { Total } \\
\text { child- } \\
\text { less }\end{array}$ & $\begin{array}{l}\text { Intend } \\
\text { No } \\
\text { child }\end{array}$ & $\begin{array}{c}\frac{\text { to have }}{\text { Child- }} \\
\text { ren }\end{array}$ \\
\hline Total $(\%)$ & 1483 & 85.7 & 8.6 & 77.1 & 1499 & 38.6 & 11.9 & 26.7 & 1912 & 21.2 & 17.0 & 4.2 \\
\hline 5-year age groups & & & & & & & & & & & & \\
\hline 1st 5-year age group & 757 & 93.8 & 7.9 & 85.9 & 733 & 47.8 & 10.0 & 37.8 & 943 & 23.4 & 17.6 & 5.8 \\
\hline 2nd 5-year age group & 726 & 77.1 & 9.2 & 67.9 & 766 & 29.8 & 13.7 & 16.1 & 969 & 19.1 & 16.4 & 2.7 \\
\hline Marital status & & & & & & & & & & & & \\
\hline Married & 213 & 51.6 & 6.1 & 45.5 & 867 & 23.0 & 5.7 & 17.3 & 1253 & 9.6 & 8.1 & 1.5 \\
\hline Common-law & 236 & 64.4 & 12.3 & 52.1 & 267 & 35.6 & 15.4 & 20.2 & 287 & 32.4 & 29.6 & 2.8 \\
\hline Wid/Div/Separated & - & -- & -- & -- & 60 & 35.0 & 8.3 & 26.7 & 169 & 15.4 & 11.8 & 3.6 \\
\hline Single & 1023 & 97.5 & 8.2 & 89.3 & 304 & 86.5 & 27.0 & 59.5 & 204 & 81.8 & 58.3 & 23.5 \\
\hline
\end{tabular}

Note: Excludes men with "missing data" on intention to have child/ren.

Source: 2006 General Social Survey on Family Transitions.

to have the intention of being childfree. As seen in Table 2, for all age groups the married and formerly married men have the lowest level of childlessness. This implies that marriage mostly remains a precondition for having children. This is also evident from the high proportion of childless men, expectedly among the never-married (or single) but also among those in common-law unions.

The proportion of childless men in common-law union is more than 10 per cent higher than the proportion for married men. Likewise, in comparison to married men at given ages, the proportion intending to be childfree is 2 to 3 times higher for men in common-law unions. This could be an indication that men in common-law unions have less traditional orientations towards family life, and thus have a lower preference for having children. Other cohabiting men are in unions where their 
partners have children (Beaupré et al. 2010), and they may not feel the need to have children of their own, or they may not report the children of their partner.

The "waiting game," or the process of postponement of childbearing and eventual acceptance of childlessness, could be seen from the proportions intending to have or not to have children by marital status. At age 20-29, 80 per cent or more of childless men in each category of marital status intend to have children (Table 2, percentage intending to have children divided by percentage childless). At age 30-39, these proportions decrease to about a half or three-quarters of the childless men in each category of marital status. By age 40-49, less than 4 per cent of married men, in common-law, or formerly married intend to have children. The single are more optimistic in that 24 per cent of all single men - or 29 per cent of childless single men aged 40-49-still intend to have children. This could be an indication that partnered men have accepted their childlessness, whereas for single men over the age of 40 , having children is still considered a possibility.

Table 3. Odds ratios of childlessness and intention to remain childfree, men aged 20-49 by family life course indicators and by 10-year age groups, 2006.

\begin{tabular}{|c|c|c|c|c|c|c|c|c|}
\hline \multirow{4}{*}{$\begin{array}{l}\text { Explanatory } \\
\text { variables }\end{array}$} & \multicolumn{3}{|c|}{ Age 20-29 } & \multicolumn{3}{|c|}{ Age 30-39 } & \multicolumn{2}{|c|}{ Age $40-49$} \\
\hline & Model 1 & Model 2 & Model 3 & Model 1 & Model 2 & Model 3 & Model 1 & Model 2 \\
\hline & \multirow{2}{*}{ Childless } & \multicolumn{2}{|c|}{ Intend to be } & \multirow[b]{2}{*}{ Childless } & \multicolumn{2}{|c|}{ Intend to be } & \multirow{2}{*}{\multicolumn{2}{|c|}{$\begin{array}{cc}\text { Childless } \begin{array}{c}\text { Intend to be } \\
\text { Childfree }\end{array} \\
\end{array}$}} \\
\hline & & Childfree & Childfree & & Childfree & Childfree & & \\
\hline \multicolumn{9}{|l|}{ Life course variables } \\
\hline \multicolumn{9}{|l|}{ Age groups } \\
\hline 1st 5-year age group & 1.000 & 1.000 & 1.000 & 1.000 & 1.000 & 1.000 & 1.000 & 1.000 \\
\hline 2nd 5-year age group & $.462 * * *$ & 1.288 & $1.467 *$ & $.536 * * *$ & $2.017 * * *$ & $3.277 * * *$ & $.741 * *$ & .964 \\
\hline \multicolumn{9}{|l|}{ Marital status } \\
\hline Married & 1.000 & 1.000 & 1.000 & 1.000 & 1.000 & 1.000 & 1.000 & 1.000 \\
\hline Common-law & $1.886^{* * *}$ & $2.515 * *$ & $2.328 * *$ & $2.401 * * *$ & $3.415 * * *$ & $2.759 * * *$ & $4.909 * * *$ & $4.357 * * *$ \\
\hline Wid/Div/Separated & & & & $2.185 * * *$ & 1.044 & .631 & $1.524^{*}$ & 1.269 \\
\hline Single & $26.749 * * *$ & 1.547 & .855 & $23.983 * * *$ & $6.572 * * *$ & 1.474 & $47.980 * * *$ & $14.922 * * *$ \\
\hline
\end{tabular}

Model 1 - contrasts childless men with men who have children

Model 2 - contrasts men intending to remain childfree with men who have children or intending to have children

Model 3 - contrasts childless men intending to remain childfree with childless men intending to have children

Models exclude men with "missing data" on intention to have children.

Significance levels: $1 \% * * * ; 5 \% * * ; 10 \% *$

Source: 2006 General Social Survey on Family Transitions.

The influence of age persists after controlling for other variables. As seen in Model 1 in Table 3, the odds ratio for the second 5-year age group is less than 1 for all three age groups, indicating that in comparison to men in the first 5-year age group - that is, age 25-29 (second age group) in comparison to age 20-24 (first age group), etc.- older men are less likely to be childless. Men who were childless at younger ages became fathers as they grow older. However, the probability of becoming a father decreases with age, as indicated by the increasing odds ratios for childlessness in the second 5-year age groups: 0.462 for age $25-29,0.536$ for age 35-39, and 0.741 for age 45-49.

The proportions intending to be childfree increase as men get older, especially among still-childless men. Childless men aged 35-39 are three times as likely as men aged 30-34 to have the intention of remaining childfree, an indication (as noted above) that an adjustment of intention is made as one gets older (Model 3, Table 3). By age 45-49, the likelihood of childlessness and intentions to be childfree do not differ between the age groups 40-44 and 45-49. That is, the small differences between these two age groups found in the bivariate analysis (seen in Table 2) are shown to be statistically 
non-significant, particularly when other variables are controlled. (Model 3 for the age group 40-49 is not shown in Table 3, as almost all childless men at this age intend to remain childfree.)

Controlling for other variables, the multivariate analysis (Table 3) shows results for marital status that are largely similar to the results from the bivariate analysis. The single men category still shows significantly higher odds of being childless (Model 1 in Table 3 for all three age groups). Likewise, the odds of being childless for previously married men aged 30-39 are about the same as for men in common-law unions, both of which are higher than those of the married men. At age 40-49, the odds of previously married men being childless, although not as high as those of men in commonlaw unions, remain higher than for married men.

At age 20-29, the intention to remain childfree is not significantly different for single men in comparison to married men (Models 2 and 3, Table 3). However, at older ages the intention to be childfree becomes significantly higher for single men. Likewise, after controlling for other variables, men in common-law unions are 2 to 4 times more likely than married men to have the intention of being childfree at each of the given age groups.

\section{Structural constraints: Effects of education, personal income, and work status}

Education and personal income influence childlessness in a number of ways; their effects may be in terms of the postponement of childbearing, given that acquiring education and entering high-paying jobs require large investment of time. They could also be seen in terms of affordability of having children, as children do require investment of resources. And also, education and income could influence beliefs and attitudes about children relative to other life priorities; conversely, higher education and income may make available and preferable life styles that do not include children.

Table 4. Proportion (\%) of childless men aged 20-49 by intention to have children by structural indicators and by 10-year age groups, 2006.

\begin{tabular}{|c|c|c|c|c|c|c|c|c|c|c|c|c|}
\hline \multirow[b]{2}{*}{$\begin{array}{l}\text { Explanatory } \\
\text { variables }\end{array}$} & \multicolumn{4}{|c|}{ Age group 20-29 } & \multicolumn{4}{|c|}{ Age group 30-39 } & \multicolumn{4}{|c|}{ Age group 40-49 } \\
\hline & $\mathrm{N}$ & $\begin{array}{c}\text { Total } \\
\text { child- } \\
\text { less }\end{array}$ & $\begin{array}{c}\text { Intend } \\
\begin{array}{c}\text { No } \\
\text { child }\end{array}\end{array}$ & $\begin{array}{l}\text { to have } \\
\text { Child- } \\
\text { ren }\end{array}$ & $\mathrm{N}$ & $\begin{array}{c}\text { Total } \\
\text { child- } \\
\text { less }\end{array}$ & $\begin{array}{c}\text { Intend } \\
\begin{array}{c}\text { No } \\
\text { child }\end{array}\end{array}$ & $\begin{array}{l}\text { to have } \\
\text { Child- } \\
\text { ren }\end{array}$ & $\mathrm{N}$ & $\begin{array}{c}\text { Total } \\
\text { child- } \\
\text { less }\end{array}$ & $\begin{array}{c}\text { Intend } \\
\begin{array}{c}\text { No } \\
\text { child }\end{array}\end{array}$ & $\begin{array}{l}\text { to have } \\
\text { Child- } \\
\text { ren }\end{array}$ \\
\hline \multicolumn{13}{|l|}{ Respondent's education } \\
\hline Some HS or lower & 135 & 67.4 & 10.4 & 57.0 & 138 & 34.0 & 12.3 & 21.7 & 235 & 24.3 & 21.3 & 3.0 \\
\hline HS \& some college & 624 & 88.0 & 10.4 & 77.6 & 423 & 38.8 & 13.5 & 25.3 & 561 & 20.8 & 16.2 & 4.6 \\
\hline College & 401 & 84.8 & 7.7 & 77.1 & 448 & 32.3 & 10.9 & 21.4 & 583 & 21.6 & 18.0 & 3.6 \\
\hline University \& higher & 297 & 90.5 & 5.7 & 84.8 & 469 & 46.5 & 11.5 & 35.0 & 498 & 19.7 & 15.3 & 4.4 \\
\hline \multicolumn{13}{|l|}{ Personal income } \\
\hline Less than $\$ 20,000$ & 486 & 95.9 & 7.6 & 88.3 & 115 & 57.4 & 19.1 & 38.3 & 129 & 41.9 & 34.9 & 7.0 \\
\hline$\$ 20,000$ to $\$ 49,999$ & 587 & 82.5 & 10.6 & 71.9 & 521 & 44.2 & 13.1 & 31.1 & 515 & 27.6 & 21.4 & 6.2 \\
\hline$\$ 50,000$ and over & 231 & 75.8 & 4.8 & 71.0 & 671 & 32.0 & 8.9 & 23.1 & 993 & 16.6 & 14.1 & 2.5 \\
\hline Missing & 179 & 81.0 & 10.1 & 70.9 & 193 & 35.2 & 14.5 & 20.7 & 274 & 16.4 & 10.9 & 5.5 \\
\hline \multicolumn{13}{|c|}{ Work status in past 12 months } \\
\hline Full-time & 1042 & 82.6 & 9.0 & 73.6 & 1322 & 37.0 & 11.0 & 26.0 & 1667 & 18.9 & 15.0 & 3.9 \\
\hline Part-time & 237 & 95.8 & 7.2 & 88.6 & 59 & 62.7 & 20.3 & 42.4 & 72 & 33.3 & 25.0 & 8.3 \\
\hline Not employed & 186 & 88.7 & 5.4 & 83.3 & 99 & 48.5 & 19.2 & 29.3 & 138 & 39.9 & 31.9 & 8.0 \\
\hline
\end{tabular}

Note: Excludes men with "missing data" on intention to have child/ren.

Source: 2006 General Social Survey on Family Transitions.

At younger ages (20-29 and 30-39 years), men's levels of childlessness increase with education: at age 20-29, the proportion of university-educated men who are childless is highest, at 90 per cent, whereas the proportion childless for men with the lowest level of education is 67 per cent (Table 4). 
This reflects the postponement effect; that is, men who did not pursue higher education became parents at the time when the highly educated men were still acquiring education. This postponement is also evident from the proportions intending to have children, which are highest for the university-educated men ( 85 vs. 57 per cent for age 20-29, and 35 vs. 22 per cent for age 30-39), an indication that men who did not have children at younger ages are intending to "catch up."

In contrast, at age 40-49, men with the highest education have the lowest proportion of childlessness ( 20 per cent) and the lowest proportion intending to be childfree (15 per cent). In this age group, the postponement of entry into parenthood has less influence on childlessness. Rather, the question of affordability of children comes to the fore, which is brought out as well in the relation between personal income and childlessness. For all three age groups, the higher the income, the lower is the level of childlessness. At age 30-39, for example, the childless proportion among men with less than $\$ 20,000$ annual income is 57 per cent, whereas among men earning $\$ 50,000$ or higher, the childless proportion is 32 per cent. Likewise, in the two older age groups, the proportion intending to remain childfree is highest for men with the lowest income. When men are seen as the main breadwinner, those with higher income do intend, and can well afford, to become a parent.

That affordability is a consideration for having children is also evident in the influence of work status on levels of childlessness and the intention to be childfree. Men who are employed full-time have the lowest level of childlessness, at 83 per cent for men aged 20-29, 37 per cent for men aged 30-39, and 19 per cent for those aged 40-49 (Table 4). For the not-employed, the

Table 5. Odds ratios of childlessness and intention to remain childfree men aged $20-49$ by structural indicators and by 10-year age groups, 2006.

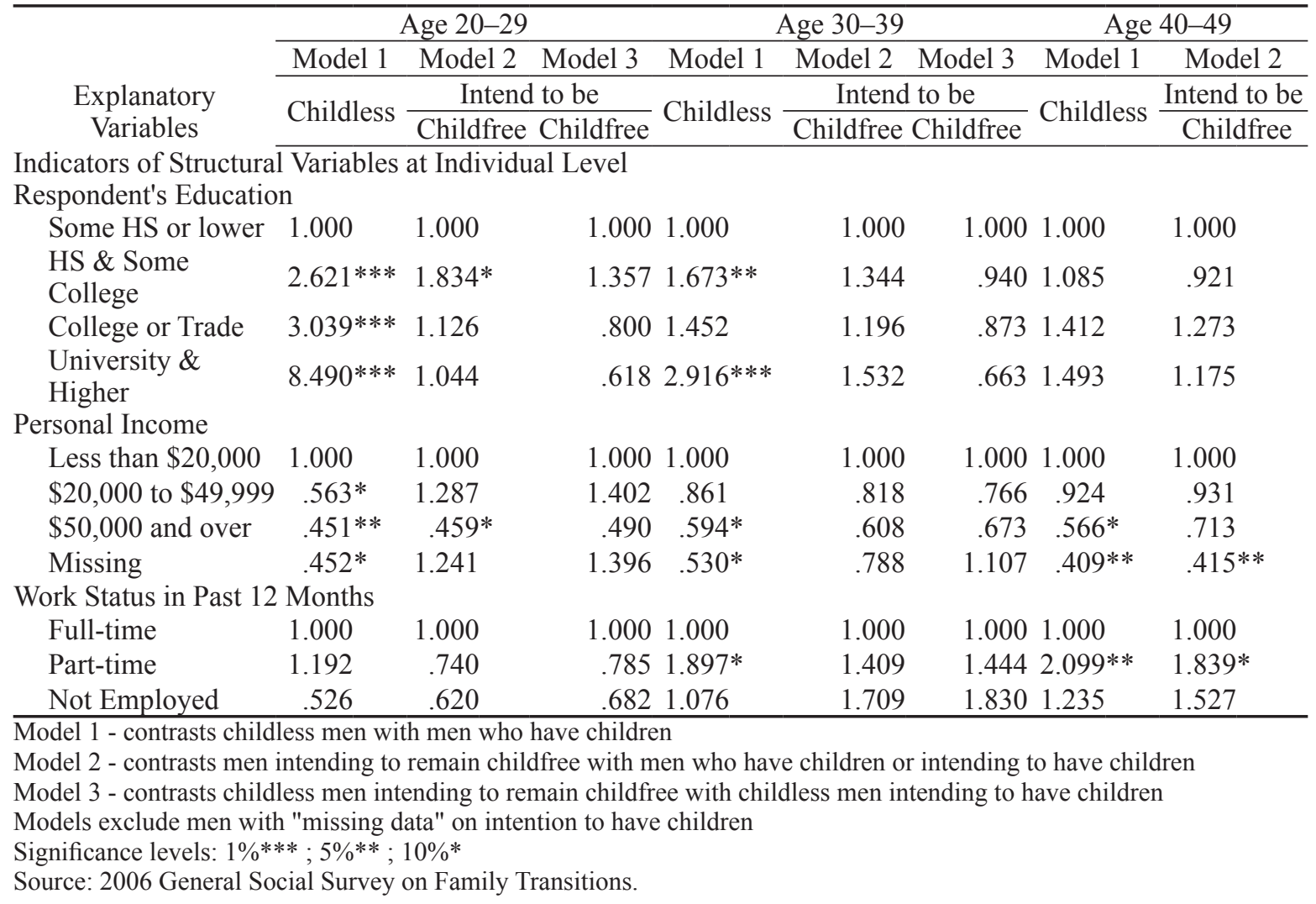


Ravanera and Beaujot: Childlessness of men in Canada

proportions childless are 89,48 , and 40 per cent for each 10-year age group, respectively. The proportion intending to remain childfree is also lowest for full-time employed men in the two older age groups.

The pattern shown in the bivariate analysis (Table 4) is largely confirmed in the multivariate analysis (Table 5). At age 20-29, level of education, with its "postponement" effect, has a highly significant effect on childlessness - the higher the education, the higher is the level of childlessness, with university-educated men 8 times more likely to be childless than the lowest-educated men. Likewise, at age 30-39 men with university education are about 3 times more likely to be childless than men with the lowest level of education (Model 1 in Table 5). In each age group, the effect of personal income on childlessness and on intention to be childfree is opposite to that of education (an effect also seen in the bivariate analysis) — that is, with higher personal income, there is lower childlessness and the intention to be childfree is less likely (Models 1, 2, and 3 in Table 5). Similarly, men employed part-time, or men not employed, are more likely to be childless, or to intend to be childfree, compared to employed men, particularly at ages 30-39 and 40-49. However, the effects of personal income and employment are not statistically significant (or only weakly sig-

nificant), possibly because income and work status, both of which are included in the model, are highly correlated and have similar influence.

In sum, the results of our analysis of the effects of structural variables point to the constraints to fatherhood - the time needed to pursue higher education and the need for full-time employment and level of income that would make having children affordable.

\section{Norms on childlessness: Effects of cultural variables and region}

The 2006 GSS data do not have information on norms regarding childlessness. However, questions about religion, religiosity, and visible minority status were asked in the survey, which we use as indicators of values related to children. In particular, those who declare a particular religious affiliation, and those who adhere to religious practices, are more likely to have family-oriented values conducive to having children. Likewise, those who identify as visible minority are more likely to have been born in countries outside of Canada, with the more recent immigrants coming mainly from Asia. They are also more likely to speak at home languages other than English and French. We thus use visible minority status as an indicator of cultural backgrounds that would point to differences in preference to having children, with visible-minority men less likely to be childless than non-visibleminority men.

As seen in Table 6, men who profess no religion have the highest proportion childless as well as the highest proportion with intention to remain childfree. This largely holds true for all three 10-year age groups, although differences are larger for the two older age groups than for the youngest age group. Similarly, men who do not at all attend religious practices have the highest proportion childless and intending to be childfree, though this holds mainly for the two older age groups 30-39 and 40-49. At age 40-49, men who do not identify as a visible minority have higher levels of childlessness, and like men in the younger age-groups, have higher proportion intending to be childfree. Noteworthy is the significantly lower level of childlessness among the non-visible minority at age 20-29 (83 per cent as against 97 per cent among the visible minority) - which is possibly due to a greater proportion among the visible minority of men who pursue higher levels of education, thereby delaying longer their transition to fatherhood. 
Table 6: Proportion (\%) of childless men aged 20-49 by intention to have children by cultural indicators and region and by 10-year age groups, 2006.

\begin{tabular}{|c|c|c|c|c|c|c|c|c|c|c|c|c|}
\hline \multirow[b]{2}{*}{$\begin{array}{l}\text { Explanatory } \\
\text { variables }\end{array}$} & \multicolumn{4}{|c|}{ Age group 20-29 } & \multicolumn{4}{|c|}{ Age group 30-39 } & \multicolumn{4}{|c|}{ Age group 40-49 } \\
\hline & $\mathrm{N}$ & $\begin{array}{l}\text { Total } \\
\text { child- } \\
\text { less }\end{array}$ & $\begin{array}{l}\text { Intend } \\
\begin{array}{c}\text { No } \\
\text { child }\end{array}\end{array}$ & $\begin{array}{l}\text { to have } \\
\text { Child- } \\
\text { ren }\end{array}$ & $\mathrm{N}$ & $\begin{array}{c}\text { Total } \\
\text { child- } \\
\text { less }\end{array}$ & $\begin{array}{l}\text { Intend } \\
\begin{array}{c}\text { No } \\
\text { child }\end{array}\end{array}$ & $\begin{array}{l}\text { to have } \\
\text { Child- } \\
\text { ren }\end{array}$ & $\mathrm{N}$ & $\begin{array}{l}\text { Total } \\
\text { child- } \\
\text { less }\end{array}$ & $\begin{array}{c}\text { Intend } \\
\begin{array}{c}\text { No } \\
\text { child }\end{array}\end{array}$ & $\begin{array}{l}\text { to have } \\
\text { Child- } \\
\text { ren }\end{array}$ \\
\hline Total (\%) & 1483 & 85.7 & 8.6 & 77.1 & 1499 & 38.6 & 11.9 & 26.7 & 1912 & 21.2 & 17.0 & 4.2 \\
\hline \multicolumn{13}{|l|}{ Culural variables } \\
\hline \multicolumn{13}{|l|}{ Religion } \\
\hline No religion & 485 & 86.6 & 11.3 & 75.3 & 421 & 45.4 & 18.8 & 26.6 & 380 & 26.6 & 22.9 & 3.7 \\
\hline Roman Catholic & 504 & 83.1 & 7.5 & 75.6 & 561 & 33.7 & 8.0 & 25.7 & 784 & 22.0 & 17.5 & 4.5 \\
\hline Protestant & 310 & 83.6 & 7.1 & 76.5 & 344 & 35.7 & 12.2 & 23.5 & 543 & 18.8 & 14.9 & 3.9 \\
\hline Other rel. \& missing & 184 & 92.9 & 6.5 & 86.4 & 172 & 43.6 & 7.0 & 36.6 & 205 & 15.2 & 9.3 & 5.9 \\
\hline \multicolumn{13}{|l|}{ Religious attendance } \\
\hline Once a week & 159 & 84.2 & 5.0 & 79.2 & 171 & 36.2 & 6.4 & 29.8 & 247 & 12.2 & 7.7 & 4.5 \\
\hline A few times a year & 586 & 87.0 & 8.5 & 78.5 & 600 & 33.8 & 6.3 & 27.5 & 810 & 17.8 & 13.6 & 4.2 \\
\hline Not at all & 694 & 85.3 & 9.2 & 76.1 & 699 & 43.8 & 18.0 & 25.8 & 805 & 27.2 & 23.5 & 3.7 \\
\hline Missing & 44 & 77.2 & 13.6 & 63.6 & 28 & 25.0 & 10.7 & 14.3 & 50 & 26.0 & 12.0 & 14.0 \\
\hline \multicolumn{13}{|l|}{ Visible minority status } \\
\hline Visible minority & 292 & 96.6 & 6.2 & 90.4 & 234 & 39.7 & 5.1 & 34.6 & 227 & 15.0 & 9.3 & 5.7 \\
\hline Non-visible minority & 1157 & 83.1 & 9.2 & 73.9 & 1246 & 38.4 & 13.2 & 25.3 & 1644 & 22.3 & 18.2 & 4.0 \\
\hline \multicolumn{13}{|c|}{ Region of residence } \\
\hline Quebec & 356 & 85.7 & 7.9 & 77.8 & 336 & 36.0 & 8.3 & 27.7 & 461 & 22.8 & 19.3 & 3.5 \\
\hline Atlantic & 101 & 81.2 & 6.9 & 74.3 & 96 & 38.6 & 11.5 & 27.1 & 137 & 19.7 & 16.8 & 2.9 \\
\hline Ontario & 553 & 88.8 & 7.2 & 81.6 & 596 & 37.2 & 9.9 & 27.3 & 744 & 20.0 & 14.0 & 6.0 \\
\hline Prairie & 281 & 81.2 & 8.2 & 73.0 & 265 & 39.6 & 17.0 & 22.6 & 322 & 19.3 & 17.1 & 2.2 \\
\hline British Columbia & 191 & 85.4 & 15.2 & 70.2 & 205 & 45.4 & 17.1 & 28.3 & 249 & 25.7 & 22.1 & 3.6 \\
\hline
\end{tabular}

Note: Excludes men with "missing data" on intention to have child/ren.

Source: 2006 General Social Survey on Family Transitions.

The high proportion preferring to be childfree among those who profess no religion, after controls for other variables, is seen in Table 7, particularly in comparison to Roman Catholic men in their 30s - who have significantly lower odds ratios, though with weaker statistical significance at age 30-39 than at age 20-29. Also, those who do not participate in religious ceremonies have significantly higher likelihood of having the intention to remain childfree, particularly at the two older age groups. Similarly, men who do not belong to the visible minority are more likely to be childless, or to prefer being childfree, in comparison to men who belong to the visible minority, although these effects are mainly significant for the age group 30-39. The lower level of childlessness among non-visible minority men at age 20-29, as seen in Table 6 , is also seen in Table 7; that is, the effect persists even after controlling for other variables.

The increments in $\mathrm{R}^{2}$ (not shown in the Tables) with inclusion of these cultural variables are smaller than for the variables earlier discussed, namely, family life course and structure variables-a possible indication that compared to education and work-related factors, values are less important determinants of childlessness and of the intention to remain childfree.

In addition to the variables discussed above, region of residence was also included in the analysis, which can be taken as an indicator of structural and cultural differences not otherwise captured by the other variables in our analysis. Quebec has the lowest level of childlessness in age group 30-39 (Table 6). In contrast, British Columbia stands out as having the highest level of childlessness in age groups 30-39 and 40-49, and also has the highest proportions of men intending to be childfree in 
all three age groups. Apart from these, childlessness and intention to be childfree do not show clear patterns by region of residence.

A clearer pattern of regional differences is seen after controlling for other variables and using Quebec as the reference category (Table 7). For the age group 20-29, the differences between regions are not statistically significant, except for the intention to remain childfree among childless men that is highest in British Columbia. At ages 30-39 and 40-49, in comparison to Quebec, childlessness and intention to be childfree is higher in all the other regions, with the differences increasing as one goes from East to West. At age 30-39, for example, in comparison to Quebec, the intention to be childfree in the Atlantic region is 1.2 times higher, but the difference is not statistically significant; in British Columbia, the odds are 2.5 higher, and the difference is highly significant.

We sought to find out why the level of childlessness and intention to be childfree did not at first have a clear pattern (as seen in Table 6), but when other variables are controlled, Quebec stands out as having the lowest level of childlessness and intention to be childfree, especially in the two older age groups (as seen in Table 7). One answer is the effect of marital status, specifically, the difference in common-law union and marriage that exists between Quebec and the rest of Canada. The level of childlessness is lower in Quebec than almost all of the other regions for each marital status (Appendix Table 3). For married men, for example, 14 per cent are childless in Quebec, whereas for all other regions in Canada,

Table 7. Odds ratios of childlessness and intention to remain childfree, men aged $20-49$ by cultural indicators and region and by 10-year age groups, 2006.

\begin{tabular}{|c|c|c|c|c|c|c|c|c|}
\hline \multirow{4}{*}{$\begin{array}{c}\text { Explanatory } \\
\text { variables }\end{array}$} & \multicolumn{3}{|c|}{ Age 20-29 } & \multicolumn{3}{|c|}{ Age 30-39 } & \multicolumn{2}{|c|}{ Age $40-49$} \\
\hline & Model 1 & Model 2 & Model 3 & Model 1 & Model 2 & Model 3 & Model 1 & Model 2 \\
\hline & \multirow{2}{*}{ Childless } & \multicolumn{2}{|c|}{ Intend to be } & \multirow{2}{*}{ Childless } & \multicolumn{2}{|c|}{ Intend to be } & \multirow{2}{*}{ Childless } & \multirow{2}{*}{$\begin{array}{c}\text { Intend to be } \\
\text { childfree }\end{array}$} \\
\hline & & Childfree & Childfree & & Childfree & Childfree & & \\
\hline \multicolumn{9}{|l|}{ Culural variables } \\
\hline \multicolumn{9}{|l|}{ Religion } \\
\hline No religion & 1.000 & 1.000 & 1.000 & 1.000 & 1.000 & 1.000 & 1.000 & 1.000 \\
\hline Roman Catholic & 1.105 & $.560 * *$ & $.552 * *$ & $.711 *$ & $.628 *$ & .826 & 1.121 & 1.006 \\
\hline Protestant & 1.239 & .696 & .696 & .915 & 1.146 & 1.433 & .957 & .896 \\
\hline Other rel. \& missing & $3.987 * *$ & .636 & .589 & 1.475 & .718 & .613 & .833 & .638 \\
\hline \multicolumn{9}{|c|}{ Religious attendance } \\
\hline Once a week & 1.000 & 1.000 & 1.000 & 1.000 & 1.000 & 1.000 & 1.000 & 1.000 \\
\hline A few times a year & 1.192 & 1.406 & 1.371 & 1.013 & 1.184 & 1.363 & $1.570^{*}$ & $1.700 *$ \\
\hline Not at all & 1.218 & 1.147 & 1.136 & 1.198 & $2.459 * *$ & $2.769 * *$ & $1.779 * *$ & $2.236 * * *$ \\
\hline Missing & $6.983 *$ & $5.347 * *$ & $3.999 *$ & .424 & .847 & 5.262 & 2.490 & .703 \\
\hline \multicolumn{9}{|l|}{ Visible minority status } \\
\hline Visible minority & 1.000 & 1.000 & 1.000 & 1.000 & 1.000 & 1.000 & 1.000 & 1.000 \\
\hline Non-visible minority & $.424 * *$ & 1.227 & 1.280 & $1.429 *$ & $2.437 * * *$ & $1.906^{*}$ & 1.359 & 1.463 \\
\hline \multicolumn{9}{|l|}{ Region of residence } \\
\hline Quebec & 1.000 & 1.000 & 1.000 & 1.000 & 1.000 & 1.000 & 1.000 & 1.000 \\
\hline Atlantic & .704 & .811 & .844 & 1.241 & 1.245 & 1.293 & $2.065 * *$ & 1.669 \\
\hline Ontario & 1.139 & .868 & .908 & $1.385^{*}$ & 1.532 & 1.473 & $2.508 * * *$ & $1.457 *$ \\
\hline Prairie & .934 & .874 & .888 & 1.433 & $2.557 * * *$ & $2.875 * * *$ & $2.079 * * *$ & $1.731 * *$ \\
\hline British Columbia & .879 & 1.696 & $1.799 *$ & $1.794 * *$ & $2.543 * * *$ & $2.379 * *$ & $3.011 * * *$ & $2.095 * * *$ \\
\hline \multicolumn{9}{|c|}{ Model 1 - contrasts childless men with men who have children } \\
\hline Model 2 - contrasts men int & tending to re & emain child & free with & & e childre & - intendin & have cl & \\
\hline Model 3 - contrasts childle & men inte & ading to $\mathrm{re}$ & in chilc & e with c & dless men it & tending to & ve childre & \\
\hline & & & & childrer & & & & \\
\hline Significance levels: $1 \% * * *$ & $* ; 5 \% * ; 1$ & $0 \% *$ & & & & & & \\
\hline & & & & & & & & \\
\hline
\end{tabular}


childlessness ranges from 17.3 per cent in the Atlantic to 23.8 per cent in British Columbia. This is also true for common-law union, where 37 per cent of men in common-law union in Quebec are childless, whereas in the rest of Canada, childlessness among cohabiting men is around 50 per cent. Thus, if one were to look at each marital status, Quebec would stand out as having the lowest level of childlessness.

However, in comparison to married men, those in a common-law union have higher levels of childlessness. This is true even for Quebec, where the difference in childlessness between married and cohabiting men is still large, at 24 per cent. Thus, the overall levels of childlessness and intention to remain childfree do not stand out as being lowest in Quebec, because the proportion of cohabiting men (32.5 per cent, see second panel, Appendix Table 3) is more than twice the proportion in each of the other regions, and the proportion of married men is about 20 per cent lower than any of the other regions.

\section{Expressed reasons for the intention to be childfree}

These findings about the relationships between individual characteristics, behaviour, and intentions could be corroborated with responses to direct questions on reasons for the intention to have a child and factors considered to be important in childbearing.

The survey included a question as to reasons for the intention not to have a child (or an additional child for those already with children): "Why is it unlikely that you will have a child?" As could be expected, for men who already have children, the answer given by the highest proportion of those in their 20s and 30s is "has enough children already," with more than 25 per cent of men aged 25-29, 30-34, and 35-39 giving this answer (Table 8). By age 40-44 and 45-49, "old age" is the most com-

Table 8. Reasons for intention not to have a/additional child, Men aged 20-49 by 5-year age groups, 2006.

\begin{tabular}{|c|c|c|c|c|c|c|}
\hline \multirow{2}{*}{$\begin{array}{l}\text { Reasons for intention not to have } \\
\text { a/additional child }\end{array}$} & \multicolumn{6}{|c|}{ Age groups } \\
\hline & $20-24$ & $25-29$ & $30-34$ & $35-39$ & $40-44$ & $45-49$ \\
\hline \multicolumn{7}{|l|}{ With Children } \\
\hline Too old & - & 0.0 & 6.7 & 12.7 & 23.3 & 44.5 \\
\hline Infertility & - & 13.8 & 17.4 & 14.1 & 14.9 & 16.6 \\
\hline Other health reasons & - & 5.2 & 5.1 & 7.3 & 6.2 & 5.1 \\
\hline Children will not fit with my life style & - & 10.3 & 5.6 & 5.9 & 7.0 & 4.0 \\
\hline My spouse/partner already has children & - & 3.4 & 2.1 & 3.3 & 2.6 & 1.9 \\
\hline My spouse/partner does not want to have children & - & 12.1 & 5.6 & 6.3 & 7.5 & 4.1 \\
\hline Has enough children & - & 27.6 & 25.1 & 28.4 & 21.1 & 15.9 \\
\hline Financial reasons & - & 8.6 & 15.4 & 11.3 & 7.3 & 3.5 \\
\hline No particular reason & - & 24.1 & 12.3 & 12.7 & 9.8 & 9.1 \\
\hline Other reasons & - & 6.9 & 9.2 & 7.0 & 10.4 & 4.7 \\
\hline Total N (who do not intend to have a/another child) & - & 58 & 195 & 426 & 644 & 749 \\
\hline \multicolumn{7}{|l|}{ Childless } \\
\hline Too old & 0.0 & 0.0 & 8.8 & 21.0 & 29.2 & 52.6 \\
\hline Infertility & 2.0 & 0.0 & 1.5 & 13.0 & 13.0 & 12.4 \\
\hline Other health reasons & 0.0 & 3.5 & 7.4 & 8.0 & 8.6 & 9.8 \\
\hline Children will not fit with my life style & 46.0 & 25.9 & 32.8 & 20.0 & 17.9 & 7.8 \\
\hline My spouse/partner already has children & 0.0 & 0.0 & 0.0 & 3.0 & 0.0 & 0.6 \\
\hline My spouse/partner does not want to have children & 0.0 & 8.8 & 9.0 & 8.9 & 4.9 & 2.0 \\
\hline Has enough children & 0.0 & 0.0 & 0.0 & 1.0 & 1.9 & 0.0 \\
\hline Financial reasons & 5.9 & 6.9 & 10.3 & 4.0 & 0.6 & 1.3 \\
\hline No particular reason & 24.0 & 24.1 & 25.0 & 14.9 & 14.3 & 9.1 \\
\hline Other reasons & 29.4 & 35.1 & 25.4 & 21.8 & 19.9 & 11.8 \\
\hline Total N (childless \& intends not to have a child) & 51 & 58 & 68 & 100 & 161 & 154 \\
\hline
\end{tabular}


mon reason for the intention not to have a child or another child. This reinforces the findings related to postponement of childbearing discussed above.

When the reasons are analyzed for childless men only, the most common reason cited by men in their 20s and 30s is "children will not fit with my lifestyle." This is also the secondmost mentioned reason for men aged 35-39 and 40-45. In contrast to men for whom the postponement of childbearing would eventually lead to an acceptance of childlessness, this answer points to men deliberately choosing to have a lifestyle free of children, particularly at an age when they may still be pursuing an education, or have not as yet established themselves in the economic realm. It is not surprising to find a high proportion (53 per cent) of childless men aged 45-49 citing "old age" as the reason for the intention to remain childfree.

An interesting, though not unexpected, pattern is that the "financial reasons" response is given by younger rather than older men, and those with children more than the childless. This reinforces the question of "affordability" of having children, particularly for young men who are still in the process of establishing themselves in the work force, and where expectations are for them to be the main breadwinners.

\section{Factors considered very important in having a child}

Respondents were also asked how important when having a/another child are health, household finances, access to maternity/paternity benefits, and work-family balance. The proportions replying "very important" are shown in Table 9. Table 9 also shows the proportion who replied that they consider other factors, and those who responded "being married or having a stable relationship" as one of those factors.

Table 9: Proportion (\%) responding "Very Important" to factors in having a/additional child, men aged 20-49 by 5-year age groups, 2006.

\begin{tabular}{lrrrrrr}
\hline & \multicolumn{5}{c}{5 -year age groups } \\
\cline { 2 - 7 } Factors for having a/additional child & $20-24$ & $25-29$ & $30-34$ & $35-39$ & $40-44$ & $45-49$ \\
\hline With children & 25.8 & 18.2 & 21.9 & 32.7 & 35.1 & 57.1 \\
$\quad$ Your age & 68.8 & 63.9 & 57.9 & 69.8 & 56.1 & 57.1 \\
$\quad$ Your health & 53.1 & 43.6 & 51.4 & 54.3 & 53.6 & 36.4 \\
$\quad$ Household finances & 25.0 & 37.7 & 39.8 & 39.6 & 35.7 & 35.0 \\
Access to maternity/paternity benefits & 56.7 & 81.3 & 70.5 & 76.2 & 83.0 & 72.2 \\
$\quad$ Work-family balance & 12.5 & 28.8 & 21.7 & 29.2 & 27.6 & 30.0 \\
Any other factor? Yes & 9.7 & 2.7 & 2.7 & 1.9 & 7.0 & 4.8 \\
$\quad$ Being married or having a stable & 31 & 110 & 183 & 107 & 57 & 21 \\
$\quad$ relationship* & & & & & & \\
\hline Total N & 36.3 & 28.0 & 20.1 & 29.4 & 27.1 & 28.0 \\
Childless & 71.9 & 69.5 & 66.3 & 65.4 & 66.1 & 63.0 \\
$\quad$ Your age & 69.1 & 66.0 & 54.5 & 57.4 & 55.9 & 76.0 \\
$\quad$ Your health & 36.1 & 36.5 & 37.2 & 29.5 & 49.1 & 44.4 \\
Household finances & 71.2 & 76.4 & 71.9 & 70.2 & 66.7 & 67.9 \\
Access to maternity/paternity benefits & 15.2 & 13.6 & 19.7 & 17.0 & 29.5 & 29.6 \\
$\quad$ Work-family balance & 10.2 & 11.0 & 7.4 & 11.0 & 16.9 & 8.0 \\
$\quad$ Any other factor? Yes & 705 & 536 & 298 & 136 & 59 & 25 \\
$\quad$ Being married or having a stable & & & & & & \\
relationship & Total N &
\end{tabular}

Source: 2006 General Social Survey on Family Transitions. 
"Work-family balance" is rated as very important by the highest proportion of men aged 25 and older (Table 9). This is possibly an indication of men's expectations-they are still considered the breadwinners, and yet, they also are expected to get more involved in family life, including doing their share of the domestic tasks and being involved in their children's lives.

The other two factors that come close, that is, rated "very important" by 50 per cent or more in almost all the age groups are "Your health" and "Household finances." Interestingly, "Access to maternity/paternity benefits" and "Your age" are rated as very important by less than 50 per cent of men in all age groups (the exception is men with children aged 45-49, with 57 per cent rating "your age" as very important).

A difference that stands out between those with children and the childless is that a higher proportion of childless men mention being married or having a stable relationship as a factor to consider in having a child. This is as expected, since the childless are more likely to be single, for whom childbearing would come only after having established relationship. Another difference is at age 45-49, only 36 per cent of men with children consider "household finances" as a very important factor in having another child, whereas 76 per cent of childless men consider "household finances" as a very important factor in having a child. This points once again to the economic constraints to fatherhood; that is, in comparison to men who have children, a greater proportion of childless men may not have adequate financial resources required for becoming a parent.

\section{Discussion and conclusion}

The data from the 2006 General Social Survey (GSS) show an increasing level of childlessness among men over birth cohorts. For example, about 24 per cent of men born in 1962-1966 were childless in 2006, which is 7 per cent higher than for men born in 1947-1951. Some of these younger men may still have children in their late 40s; however, the level of childlessness for this cohort will most likely not go below 20 per cent.

While the level of childlessness is high, the intention to be childless among younger men, say men below age 35, has largely remained low; that is, in the range of 8-10 per cent, levels that are similar to estimates from the 2001 GSS. This means that most young men have not excluded children in their life aspirations. However, the intention to be childfree increases with age such that by age 45-49, 16 per cent of men intend not to become fathers.

A picture that juxtaposes level of childlessness with level intending to be childfree shows that a part of the increase in childlessness could be the result of a waiting game rather than the result of deliberate choice. In the past few decades, young people have been staying in school longer, entering the work force later, and establishing relationships at older ages - which, in turn, delays the transition to parenthood. While for many men the delay does not necessarily end in childlessness, for others the period of waiting could change their willingness, ability, and readiness to become parents.

The normative expectation that men should be economically stable before forming a family and becoming a parent continues to prevail. Thus, as shown in our analysis, men employed full-time are more likely to have, or intend to have, a child. In the past 2-3 decades, the economic situation of young men has been at a disadvantage in comparison to older men, which no doubt has led to postponement of entry into stable relationship and parenthood, and for some, to childlessness. It is thus no surprise that at young ages (that is, 20-35 years), a high proportion of men view children as not fitting into a lifestyle that possibly includes years of schooling and seeking to be economically stable. The lifestyle factor is also related to changing norms about having a child, previously considered as 
Ravanera and Beaujot: Childlessness of men in Canada

inevitable but now largely considered as a choice left to individuals. That is, adjusting one's intention not to become a parent is made easier by easing the normative pressure to have children, often referred to as "parenthood mystique."

While the role of men as main breadwinner has not drastically changed, their role vis-à-vis children has changed in other ways. There is now greater expectation that men should be more involved in taking care of children, a responsibility born mainly by women in the past. This expectation is possibly why, in comparison to other reasons such as health, age, and access to parental leaves, a greater proportion of men consider "work-life balance" as a very important factor in having a child. This could contribute to childlessness, in that men may further delay having a child as they consider their readiness for fatherhood.

Finally, a further question that needs to be asked is why childlessness matters. A common answer is that childlessness contributes to decreasing fertility, which in turn results in population aging. At the individual level, young people do seem to have children as part of their life goals, but many are hindered from achieving this goal, largely due to difficulties and delays in establishing themselves economically. Furthermore, although some studies show that being childfree does not lead to negative consequences in later life (Albertini and Kohli 2009; Wenger 2009), other studies have shown the benefits of fatherhood, particularly in terms of having a wider network of friends and family (Connidis 2001: 162; Ravanera 2007). As Connidis (2009) notes, the increasing involvement of men in children's lives could deepen the divide between fathers and childless men. It thus becomes important for society to help young people facilitate transition to a family life that includes children. This could come in the form of policies and practices in the economy that would benefit younger men, and social policies (such as day care facilities and provisions for parental leave) that would help ease the work-life balance concerns of couples.

\section{References}

Albertini, M., and K. Martin. 2009. What childless older people give: Is the generational link broken? Ageing \& Society 29:1261-1274.

Aries, P. 1980. Two successive motivations for the declining birth rate in the West. Population and Development Review 6.4:645-650.

Beaujot, R. 2000. Earning and Caring in Canadian Families. Peterborough: Broadview.

Beaujot, R., and A. Muhammad. 2006. Transformed families and basis for childbearing, in Canada's Changing Families: Implications for Individuals and Society, edited by K. McQuillan and Z.R. Ravanera. Toronto: University of Toronto Press, pp. 15-48.

Beaujot, R., Z.R. Ravanera, and T.K. Burch. 2007. Toward an HRSDC family research framework. Paper presented at the Social Development Canada Expert roundtable on Challenges for Canadian Families, Ottawa, 1-2 December 2005. Population Studies Centre Discussion Paper No. 07-02: http://sociology.uwo.ca/popstudies/dp/dp07-02.pdf

Beaujot, R., Z. Ravanera, and C. Du. 2010. Child care: Preferences and opportunity costs. Paper presented at Statistics Canada Socio-Economic Conference, 26-27 April.

Beaujot, R., Z. Ravanera, and J. Liu. 2008. Models of earning and caring: Trends, determinants and implications. Report prepared for Human Resources and Skills Development Canada, and presented at the Conference on Monitoring Canadian Families over the Lifecourse, Ottawa, September 25. 
Bingoly-Liworo, G. 2010. The influence of characteristics of men's job on the timing of the first birth in Canada. Canadian Studies in Population 37(1-2):77-105.

Beaupré, P., H. Dryburgh, and M. Wendt. 2010. Making fathers “count." Canadian Social Trends 90:26-34.

Blackstone, A., and M.D. Stewart. 2012. Choosing to be childfree: Research on the decision not to parent. Sociology Compass 6(9):718-727.

Clark, W. 2000. "100 years of education.” Canadian Social Trends 59:3-7.

Connidis, I.A. 2001. Family Ties and Aging. Thousand Oaks, CA: Sage Publications.

- 2009. Family Ties and Aging. Pine Forge Press.

Goldscheider, F., D. Hogan, and P. Turcotte. 2006. The other partner: The changing role of 'Good Provider' in men's union formation patterns in industrialized countries. Canadian Studies in Population 33(1):25-48.

Heaton, T.B., C.K. Jacobson, and K. Holland. 1999. Persistence and change in decisions to remain childless. Journal of Marriage and Family 61(2):531-539.

Heckhausen, J. 1999. Developmental Regulation in Adulthood: Age-Normative and Sociostructural Constraints as Adaptive Challenges. Cambridge University Press.

Juby, H., and C. Le Bourdais. 1999. Where have all the children gone? Comparing mothers' and fathers' declarations in retrospective surveys. Canadian Studies in Population 26(1):1-20.

Lapierre-Adamcyk, E. 1990. Faire face au changement démographique : la nécessaire partricipation des femmes, in Faire Face au Changement Démographique, edited by R. Beaujot. Ottawa: Royal Society of Canada.

Lesthaeghe, R. 1995. The second demographic transition in western countries: An interpretation, in Gender and Family Change in Industrialized Countries, edited by K. Oppenheim Mason and A-M. Jensen, Oxford: Clarendon Press, pp. 17-62.

May, E. T. (1995). Barren in the Promised Land: Childless Americans and the Pursuit of Happiness. New York: Basic Books.

Morissette, R. 2002. Cumulative earnings among young workers. Perspectives on Labour and Income 14(4):33-40.

Morissette, R. 2008. Earnings in the last decade. Perspectives on Labour and Income 20(1):57-69.

Morissette, R., and A. Johnson. 2005. Are good jobs disappearing in Canada? Statistics Canada Analytical Studies Branch research paper series, Catalogue no. 11F0019MIE — No. 239.

Oppenheimer, V., and A. Lewin. 1999. Career development and marriage formation in a period of rising inequality: Who is at risk? What are the prospects? In Transitions to Adulthood in a Changing Economy: No Work, No Family, No Future?, edited by A. Booth, A. Crouter, and M. Shanahan. Westport: Praeger Publishers, pp. 189-225.

Park, K. 2002. Stigma management among the voluntarily childless. Sociological Perspectives 45(1):21-45.

Ravanera, Z.R. 2007. Informal networks social capital of fathers: What does the social engagement survey tell us? Social Indicators Research 83(2):351-373.

Ravanera, Z.R., T.K. Burch, and F. Rajulton. 2006. Men's life course trajectories: Exploring the differences by cohort and social class. Social Biology 53(3-4):120-139. 
Ravanera, Z.R., R. Beaujot, and J. Liu. 2009. Models of earning and caring: Determinants of the division of work. Canadian Review of Sociology 46(4):319-337.

Rendall, M., L. Clarke, H.E. Peters, N. Ranjit, and G. Verropoulou. 1997. Incomplete Reporting of Male Fertility in the United States and Britain. Beijing: IUSSP Paper.

Statistics Canada. 2008. General Social Survey Cycle 20: Family Transitions (2006) Public Use Microdata File Documentation and User's Guide. Catalogue No. 12M0020G.

Stobert, S., and A. Kemeny. 2003. Childfree by choice. Canadian Social Trends. Summer 2003: 7-10.

Veevers, J. 1980. Childless by Choice. Toronto: Butterworths.

Wenger, G.C. 2009. Childlessness at the end of Life: Evidence from rural Wales. Ageing \& Society 29:1243-1259. 
Appendix Table 1. Proportion (\%) of childless men by intention to have children, aged 20-49, by 10 -year age groups and various explanatory variables, 2006.

\begin{tabular}{|c|c|c|c|c|c|c|c|c|c|c|c|c|}
\hline \multirow[b]{2}{*}{$\begin{array}{l}\text { Explanatory } \\
\text { variables }\end{array}$} & \multicolumn{4}{|c|}{ Age group 20-29 } & \multicolumn{4}{|c|}{ Age group 30-39 } & \multicolumn{4}{|c|}{ Age group 40-49 } \\
\hline & $\mathrm{N}$ & $\begin{array}{c}\text { Total } \\
\text { child- } \\
\text { less }\end{array}$ & $\begin{array}{l}\text { Intend } \\
\begin{array}{c}\text { No } \\
\text { child }\end{array}\end{array}$ & $\begin{array}{c}\text { to have } \\
\text { child- } \\
\text { ren }\end{array}$ & $\mathrm{N}$ & $\begin{array}{l}\text { Total } \\
\text { child- } \\
\text { less }\end{array}$ & $\begin{array}{l}\text { Intend } \\
\begin{array}{c}\text { No } \\
\text { child }\end{array}\end{array}$ & $\begin{array}{c}\text { to have } \\
\text { child- } \\
\text { ren }\end{array}$ & $\mathrm{N}$ & $\begin{array}{c}\text { Total } \\
\text { child- } \\
\text { less }\end{array}$ & $\begin{array}{c}\text { Intend } \\
\begin{array}{c}\text { No } \\
\text { child }\end{array}\end{array}$ & $\begin{array}{c}\text { to have } \\
\text { child- } \\
\text { ren }\end{array}$ \\
\hline Total (\%) & 1483 & 85.7 & 8.6 & 77.1 & 1499 & 38.6 & 11.9 & 26.7 & 1912 & 21.2 & 17.0 & 4.2 \\
\hline \multicolumn{13}{|c|}{ Family Life Course Variables } \\
\hline 1 st 5 -year age group & 757 & 93.8 & 7.9 & 85.9 & 733 & 47.8 & 10.0 & 37.8 & 943 & 23.4 & 17.6 & 5.8 \\
\hline 2nd 5- year age group & 726 & 77.1 & 9.2 & 67.9 & 766 & 29.8 & 13.7 & 16.1 & 969 & 19.1 & 16.4 & 2.7 \\
\hline \multicolumn{13}{|c|}{ Marital status } \\
\hline Married & 213 & 51.6 & 6.1 & 45.5 & 867 & 23.0 & 5.7 & 17.3 & 1253 & 9.6 & 8.1 & 1.5 \\
\hline Common-law & 236 & 64.4 & 12.3 & 52.1 & 267 & 35.6 & 15.4 & 20.2 & 287 & 32.4 & 29.6 & 2.8 \\
\hline Wid/Div/Separated & - & - & - & - & 60 & 35.0 & 8.3 & 26.7 & 169 & 15.4 & 11.8 & 3.6 \\
\hline Single & 1023 & 97.5 & 8.2 & 89.3 & 304 & 86.5 & 27.0 & 59.5 & 204 & 81.8 & 58.3 & 23.5 \\
\hline \multicolumn{13}{|c|}{ Cultural Variables } \\
\hline No religion & 485 & 86.6 & 11.3 & 75.3 & 421 & 45.4 & 18.8 & 26.6 & 380 & 26.6 & 22.9 & 3.7 \\
\hline Roman Catholic & 504 & 83.1 & 7.5 & 75.6 & 561 & 33.7 & 8.0 & 25.7 & 784 & 22.0 & 17.5 & 4.5 \\
\hline Protestant & 310 & 83.6 & 7.1 & 76.5 & 344 & 35.7 & 12.2 & 23.5 & 543 & 18.8 & 14.9 & 3.9 \\
\hline Other rel. \& missing & 184 & 92.9 & 6.5 & 86.4 & 172 & 43.6 & 7.0 & 36.6 & 205 & 15.2 & 9.3 & 5.9 \\
\hline \multicolumn{13}{|l|}{ Religious attendance } \\
\hline Once a week & 159 & 84.2 & 5.0 & 79.2 & 171 & 36.2 & 6.4 & 29.8 & 247 & 12.2 & 7.7 & 4.5 \\
\hline A few times a year & 586 & 87.0 & 8.5 & 78.5 & 600 & 33.8 & 6.3 & 27.5 & 810 & 17.8 & 13.6 & 4.2 \\
\hline Not at all & 694 & 85.3 & 9.2 & 76.1 & 699 & 43.8 & 18.0 & 25.8 & 805 & 27.2 & 23.5 & 3.7 \\
\hline Missing & 44 & 77.2 & 13.6 & 63.6 & 28 & 25.0 & 10.7 & 14.3 & 50 & 26.0 & 12.0 & 14.0 \\
\hline \multicolumn{13}{|l|}{ Visible minority status } \\
\hline Visible minority & 292 & 96.6 & 6.2 & 90.4 & 234 & 39.7 & 5.1 & 34.6 & 227 & 15.0 & 9.3 & 5.7 \\
\hline Non-visible minority & 1157 & 83.1 & 9.2 & 73.9 & 1246 & 38.4 & 13.2 & 25.3 & 1644 & 22.3 & 18.2 & 4.0 \\
\hline \multicolumn{13}{|c|}{ Structural Variables at Individual Level } \\
\hline Some HS or lower & 135 & 67.4 & 10.4 & 57.0 & 138 & 34.0 & 12.3 & 21.7 & 235 & 24.3 & 21.3 & 3.0 \\
\hline HS \& some college & 624 & 88.0 & 10.4 & 77.6 & 423 & 38.8 & 13.5 & 25.3 & 561 & 20.8 & 16.2 & 4.6 \\
\hline College or trade & 401 & 84.8 & 7.7 & 77.1 & 448 & 32.3 & 10.9 & 21.4 & 583 & 21.6 & 18.0 & 3.6 \\
\hline University \& higher & 297 & 90.5 & 5.7 & 84.8 & 469 & 46.5 & 11.5 & 35.0 & 498 & 19.7 & 15.3 & 4.4 \\
\hline \multicolumn{13}{|l|}{ Personal income } \\
\hline Less than $\$ 20,000$ & 486 & 95.9 & 7.6 & 88.3 & 115 & 57.4 & 19.1 & 38.3 & 129 & 41.9 & 34.9 & 7.0 \\
\hline$\$ 20,000$ to $\$ 49,999$ & 587 & 82.5 & 10.6 & 71.9 & 521 & 44.2 & 13.1 & 31.1 & 515 & 27.6 & 21.4 & 6.2 \\
\hline$\$ 50,000$ and over & 231 & 75.8 & 4.8 & 71.0 & 671 & 32.0 & 8.9 & 23.1 & 993 & 16.6 & 14.1 & 2.5 \\
\hline Missing & 179 & 81.0 & 10.1 & 70.9 & 193 & 35.2 & 14.5 & 20.7 & 274 & 16.4 & 10.9 & 5.5 \\
\hline \multicolumn{13}{|c|}{ Work status in past 12 months } \\
\hline Full-time & 1042 & 82.6 & 9.0 & 73.6 & 1322 & 37.0 & 11.0 & 26.0 & 1667 & 18.9 & 15.0 & 3.9 \\
\hline Part-time & 237 & 95.8 & 7.2 & 88.6 & 59 & 62.7 & 20.3 & 42.4 & 72 & 33.3 & 25.0 & 8.3 \\
\hline Not employed & 186 & 88.7 & 5.4 & 83.3 & 99 & 48.5 & 19.2 & 29.3 & 138 & 39.9 & 31.9 & 8.0 \\
\hline \multicolumn{13}{|l|}{ Region of residence } \\
\hline Quebec & 356 & 85.7 & 7.9 & 77.8 & 336 & 36.0 & 8.3 & 27.7 & 461 & 22.8 & 19.3 & 3.5 \\
\hline Atlantic & 101 & 81.2 & 6.9 & 74.3 & 96 & 38.6 & 11.5 & 27.1 & 137 & 19.7 & 16.8 & 2.9 \\
\hline Ontario & 553 & 88.8 & 7.2 & 81.6 & 596 & 37.2 & 9.9 & 27.3 & 744 & 20.0 & 14.0 & 6.0 \\
\hline Prairie & 281 & 81.2 & 8.2 & 73.0 & 265 & 39.6 & 17.0 & 22.6 & 322 & 19.3 & 17.1 & 2.2 \\
\hline British Columbia & 191 & 85.4 & 15.2 & 70.2 & 205 & 45.4 & 17.1 & 28.3 & 249 & 25.7 & 22.1 & 3.6 \\
\hline
\end{tabular}

Note: Excludes men with "missing data" on intention to have child/ren.

Source: 2006 General Social Survey on Family Transitions. 
Ravanera and Beaujot: Childlessness of men in Canada

Appendix Table 2. Odds ratios of childlessness and intention to remain childfree, men aged 20-49 by 10year age groups, 2006.

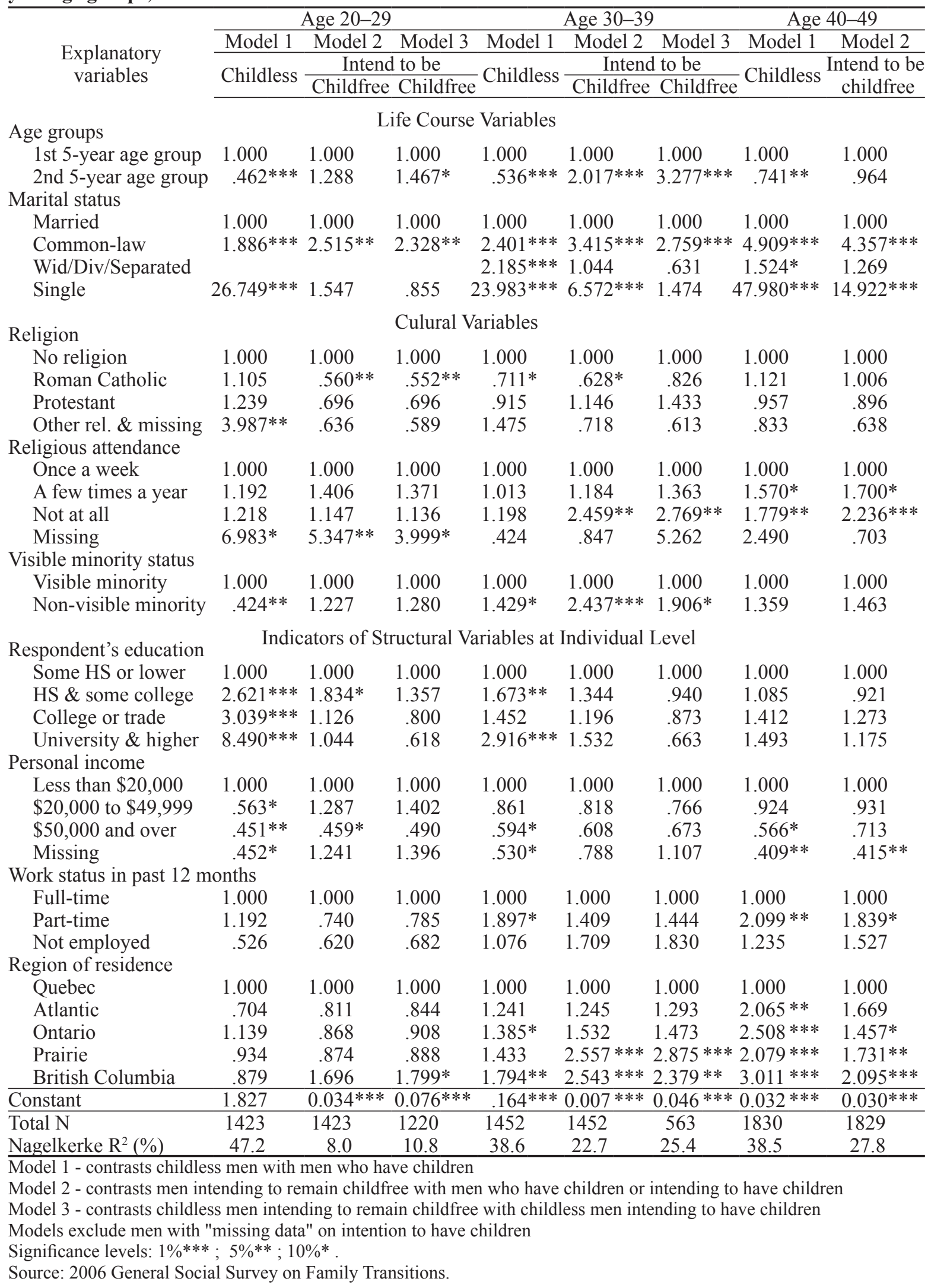


Appendix Table 3. Percentage childless and percentage distribution, men aged $20-49$ by marital status and by region, 2006.

\begin{tabular}{|c|c|c|c|c|c|c|}
\hline & Quebec & $\begin{array}{l}\text { Atlantic } \\
\text { Region }\end{array}$ & Ontario & $\begin{array}{l}\text { Prairie } \\
\text { Region }\end{array}$ & $\begin{array}{c}\text { British } \\
\text { Columbia }\end{array}$ & Total \\
\hline Marital Status & \multicolumn{6}{|c|}{ Percentage Childless } \\
\hline Married & 13.6 & 17.3 & 18.0 & 19.5 & 23.8 & 18.4 \\
\hline Common-law & 37.4 & 50.0 & 47.3 & 48.7 & 50.0 & 43.1 \\
\hline Widowed, divorced, separated & 12.2 & 25.0 & 26.9 & 21.6 & 30.0 & 23.5 \\
\hline \multirow[t]{2}{*}{ Single } & 89.5 & 88.2 & 95.8 & 92.7 & 96.0 & 93.3 \\
\hline & \multicolumn{6}{|c|}{ Percentage Distribution by Marital Status } \\
\hline Married & 30.8 & 49.9 & 52.2 & 50.3 & 51.6 & 46.6 \\
\hline Common-law & 32.5 & 14.3 & 8.5 & 12.8 & 11.1 & 15.6 \\
\hline Widowed, divorced, separated & 3.5 & 3.8 & 5.9 & 5.6 & 4.8 & 5.0 \\
\hline Single & 33.2 & 32.1 & 33.4 & 31.4 & 32.5 & 32.8 \\
\hline
\end{tabular}

Source: 2006 General Social Survey on Family Transitions. 